\title{
Effects of host plants on digestive enzymatic activities and some components involved in intermediary metabolism of Chrysodeixis chalcites (Lepidoptera: Noctuidae)
}

\author{
M. Mardani-Talaee, ${ }^{1}$ V. Rahimi, ${ }^{2}$ A. Zibaee $^{2}$ \\ ${ }^{1}$ Department of Plant Protection, University of Mohaghghegh-Ardabili; ${ }^{2}$ Department of Plant \\ Protection, University of Guilan, Rasht, Iran
}

\begin{abstract}
Chrysodeixis chalcites (Esper) is a serious pest that causes devastating damages in infested areas to many fruits, vegetables, ornamental crops and weeds. In the current study, effects of three host plants including lemon balm (Melissa officinalis L.); corn (Zea mays L.) and dill (Anethum graveolens L.) were determined on digestive enzyme activities and intermediary metabolism of $C$. chalcites larvae. The highest activities of $\alpha$-amylase, glucosidases and specific proteases were observed in the larvae fed on dill. Our results showed that $C$. chalcites larvae had the highest TAG-lipase activity on corn in comparison with other host plants. Significant differences were found among enzymatic activities of acid (ACP) and alkaline phosphatases, aspartate aminotransferases and lactate dehydrogenase (LDH) in the haemolymph of $C$. chalcites larvae reared on lemon balm, corn and dill, respectively, although activity of alanine aminotransferase showed no statistically significant differences among different host plants. The enzymatic activity of ACP significantly decreased on dill in comparison with lemon balm and corn. The activity of LDH significantly increased on dill compared with other host plants. These results revealed that dill (A. graveolens) is the most appropriate host plant for larvae of $C$. chalcites as evidenced by the highest digestive enzyme activities and intermediary metabolism.
\end{abstract}

Correspondence: Arash Zibaee, Department of Plant Protection, University of Guilan, Iran.

Tel.: +98.0131.6690284 - Fax: +98.0131.6690281.

E-mail: arash.zibaee@gmx.com ; arash.zibaee@guilan.ac.ir

Key words: Chrysodeixis chalcites, digestive enzyme, intermediary metabolism, host plant.

Received for publication: 9 March 2014.

Revision received: 2 June 2014.

Accepted for publication: 13 June 2014.

(C) Copyright M. Mardani-Talaee et al., 2014

Licensee PAGEPress, Italy

Journal of Entomological and Acarological Research 2014; 46:3224

doi:10.4081/jear.2014.3224

This article is distributed under the terms of the Creative Commons Attribution Noncommercial License (by-nc 3.0) which permits any noncommercial use, distribution, and reproduction in any medium, provided the original author(s) and source are credited.

\section{Introduction}

The golden twin spot, also known as the tomato looper, Chrysodeixis chalcites (Esper) (Lepidoptera: Noctuidae), is a serious pest native to Mediterranean and tropical regions. It is a polyphagous and a polyvoltine pest that causes severe damage in both fields and greenhouses. The larvae of $C$. chalcites intensively utilise leaves and fruits of agricultural crops as well as weeds in many plant families (Rashid et al., 1971; Broza \& Sneh, 1994). Females lay their eggs on host leaves, and first instars graze on the undersides of leaves, feeding on parenchyma and then dropping from the leaf to hang on a silken thread, which enables wind dispersal (Goodey, 1991). During the II and III instars, the larvae roll the edges of leaves (Rashid et al., 1971). The later instars, mainly V and VI, are the most voracious feeders, and utilise the entire leaf except for the midrib and other large veins (Taylor \& Kunjecku, 1983).

The quality and quantity of host plants are the most important factors in the survival and reproduction of an insect. Each host plant contains several nutritional and anti-nutritional substances, for which regulation of their uptake by an insect represents integration of a highly complex set of interacting processes (Simpson \& Raubenheimer, 1999). However, many plants synthesise various inhibitors, such as $\alpha$-amylase and protease inhibitors, that may affect feeding and other physiological functions of phytophagous insects (Hsiao \& Fraenkel, 1968; Ryan, 1990). In the case of polyphagous insects, the presence of different host plants could trigger population outbreaks because insect growth, development and reproduction are strongly dependent on the quality and the quantity of food utilised (Simpson \& Raubenheimer, 1999).

Digestive performance involves processes leading to insect host plant choice. In addition to secondary substances, other factors provide a choice among viable hosts, including nutritional components, plant physical characteristics, and levels of attractive volatile substances (Chew \& Renwick, 1995; Bittencourt-Rodrigues \& Zucoloto, 2005). Accordingly, different host plants affect digestive performance in an insect, owing to variations in amounts of nutritional components and possible inhibitors, as well as secondary metabolites. Also, insects recruit a complex of digestive enzymes, including carbohydrases, lipases and proteases, to break down ingested food. Any changes in utilised food can alter the activities of these enzymes and subsequent processes, mainly those involved in intermediary metabolism. Because C. chalcites is a polyphagous insect, it may rely on various digestive enzymes whose activity could fluctuate when different host plants are utilised. The aim of the current study was to determine the effects of larval feeding on three host plants of $C$. chalcites including lemon balm (Melissa officinalis), corn (Zea mays) and dill (Anethum graveolens) on digestive enzyme activities and components involved in intermediary metabolism. 


\section{Materials and methods}

\section{Insect rearing}

Larvae of $C$. chalcites were obtained from a tomato field and reared in a growth chamber at $25 \pm 1^{\circ} \mathrm{C}, 65 \pm 5 \%$ relative humidity and a photoperiod of 16:8 L:D h. Larvae were reared separately on the three host plants, lemon balm (M. officinalis), corn (Z. mays) and dill (A. graveolens), from instars I to $\mathrm{V}$.

\section{Sample preparation}

Larvae fed on each host plant were randomly selected and dissected in distilled ice water. The midguts were removed, placed in distilled water and homogenised with a hand-held glass pestle. Homogenate samples were centrifuged at $24,000 \mathrm{~g}$ for $10 \mathrm{~min}$ at $4^{\circ} \mathrm{C}$. The supernatants were pooled and stored at $-20^{\circ} \mathrm{C}$ for subsequent analyses.

\section{$\boldsymbol{\alpha}$-amylase assay}

The method of Bernfeld (1955) was used to assay $\alpha$-amylase activity using starch (1\%) as a substrate and dinitrosalicylic acid (DNS) as a stopper. Ten microliters of the enzyme was incubated for $30 \mathrm{~min}$ at $35^{\circ} \mathrm{C}$ in $50 \mu \mathrm{L}$ of universal buffer $(0.02 \mathrm{M}, \mathrm{pH} 7)$ and $30 \mu \mathrm{L}$ of soluble starch. The reaction was stopped by adding $80 \mu \mathrm{L}$ of DNS and heated in boiling water for $10 \mathrm{~min}$ prior to being read at $545 \mathrm{~nm}$. One unit of $\alpha$ amylase activity was defined as the amount of enzyme required to produce $1 \mathrm{mg}$ maltose in $30 \mathrm{~min}$ at $35^{\circ} \mathrm{C}$.

\section{$\alpha$ - and $\beta$-glucosidase assay}

Activities of $\alpha$ - and $\beta$-glucosidase were assayed according to the method of Silva \& Terra (1995), with slight modifications. Assays were performed in $10 \mathrm{mM}$ of universal buffer at $\mathrm{pH} 7.0$ and $30^{\circ} \mathrm{C}$. Reaction mixtures consisted of buffer $(50 \mu \mathrm{L})$, enzyme extract $(15 \mu \mathrm{L})$ and substrate $(30 \mu \mathrm{L})(p$-nitrophenol $\alpha$-glucopyranoside for $\alpha$-glucosidase and $p$-nitrophenol $\beta$-glucopyranoside for $\beta$-glocusidase). The reactions were terminated after $10 \mathrm{~min}$ and production of $p$-nitrophenol was measured at a wavelength of $405 \mathrm{~nm}$.

\section{General protease assay}

General proteolytic activity was assayed in the midgut of $C$. chalcites using haemoglobin $(20 \mathrm{mg} / \mathrm{mL}$ ) as a substrate (Cohen, 1993). Haemoglobin solution ( $50 \mu \mathrm{L}$ ) was added to $100 \mu \mathrm{L}$ of universal buffer (pH 9). After adding $20 \mu \mathrm{L}$ of enzyme solution, incubation was continued for $120 \mathrm{~min}$ at $30^{\circ} \mathrm{C}$. For termination of proteolysis, $150 \mu \mathrm{L}$ of $10 \%$ trichloroacetic acid (TCA) was added to the reaction mixture. Precipitation was achieved by cooling at $4^{\circ} \mathrm{C}$ for $5 \mathrm{~min}$ and the reaction mixture was centrifuged at $13,000 \mathrm{rpm}$ for $10 \mathrm{~min}$. The peptides liberated from haemoglobin were estimated using Folin-Phenol reagent at $630 \mathrm{~nm}$ (Folin \& Ciocalteu, 1927).

\section{Triacylglyceride lipase assay}

A triacylglyceride (TAG)-lipase assay was carried out using the method of Tsujita et al. (1989). Twenty microliters of the gut extract and $40 \mu \mathrm{L}$ of $p$-nitrophenyl butyrate $(27 \mathrm{mM})$ as a substrate were added to $100 \mu \mathrm{L}$ of universal buffer $(10 \mathrm{mM}, \mathrm{pH} 7)$, mixed thoroughly and incubated at $37^{\circ} \mathrm{C}$. After $1 \mathrm{~min}, 100 \mu \mathrm{L}$ of $\mathrm{NaOH}(1 \mathrm{M})$ was added to each tube and absorbance was read at $405 \mathrm{~nm}$. One unit of enzyme will release $1.0 \mathrm{nmol}$ of $p$-nitrophenol per min at $\mathrm{pH} 7.2$ and $37^{\circ} \mathrm{C}$ when $p$ nitrophenyl butyrate is used as a substrate. The standard curve of $p$ nitrophenol was used to calculate the specific activity of the enzyme.

\section{Determination of the presence of specific proteases}

\section{Serine proteinases}

Trypsin-, chymotrypsin-, and elastase-like activities (as three subclasses of serine proteinases) were assayed using $1 \mathrm{mM}$ of BApNA (Nabenzoyl-DL-arginine- $p$-nitroanilide), 1 mM SAAPPpNA ( $N$-succinyl-alanine-alanine-proline-phenylalanine-p-nitroanilide), and $1 \mathrm{mM}$ SAAApNA ( $N$-succinyl-alanine-alanine-alanine- $p$-nitroanilide) as substrates, respectively. The reaction mixtures included $50 \mu \mathrm{L}$ of universal buffer $(20 \mathrm{mM}, \mathrm{pH} 8), 20 \mu \mathrm{L}$ of each substrate mentioned above and 10 $\mu \mathrm{L}$ of enzyme solution. The reaction mixtures were incubated at $30^{\circ} \mathrm{C}$ for a period of from 0 to 10 min before adding $30 \%$ TCA to terminate the reactions. The absorbance was read at $405 \mathrm{~nm}$.

\section{Exopeptidases}

Two exopeptidases in the midgut of $C$. chalcites were assayed using hippuryl-L-arginine and hippuryl-L-phenylalanine for carboxy- and aminopeptidases, respectively. The reaction mixture consisted of $50 \mu \mathrm{L}$ of universal buffer ( $\mathrm{pH} 7$ ), $30 \mu \mathrm{L}$ of each substrate and $15 \mu \mathrm{L}$ of enzyme solution. The reaction mixture was incubated at $30^{\circ} \mathrm{C}$ for a period of 0 to $10 \mathrm{~min}$ before adding $30 \%$ TCA to terminate the reaction and reading at $340 \mathrm{~nm}$.

\section{Triacylglyceride determination}

A diagnostic kit (Pars Azmoon Co., Tehran, Iran) was used to measure the amount of triacylglyceride in the $\mathrm{V}$-instar larvae. The reagent solution contained phosphate buffer $(50 \mathrm{mM}, \mathrm{pH} 7.2)$, 4-chlorophenol (4 mM), adenosine triphosphate $(2 \mathrm{mM}), \mathrm{Mg}^{2+}(15 \mathrm{mM})$, glycerokinase $(0.4 \mathrm{kU} / \mathrm{L})$, peroxidase $(2 \mathrm{kU} / \mathrm{L})$, lipoprotein lipase $(2 \mathrm{kU} / \mathrm{L}), 4$ aminoantipyrine $(0.5 \mathrm{mM})$ and glycerol-3-phosphate-oxidase $(0.5$ $\mathrm{kU} / \mathrm{L})$. Samples $(10 \mu \mathrm{L})$ were incubated with $10 \mu \mathrm{L}$ of distilled water and $70 \mu \mathrm{L}$ of reagent for $20 \mathrm{~min}$ at $25^{\circ} \mathrm{C}$ (Fossati \& Prencipe, 1982). Optical densities (ODs) of samples and reagent as a standard were read at $546 \mathrm{~nm}$. The following equation was used to calculate the amount of triacylglyceride:

$$
\mathrm{mg} / \mathrm{dL}=\frac{\text { OD of sample }}{\text { OD of standard }} \times 0.01126
$$

\section{Glycogen determination}

The fat bodies of five larvae were cut and immersed in $1 \mathrm{~mL}$ of $30 \%$ $\mathrm{KOH}$ with $\mathrm{Na}_{2} \mathrm{SO}_{4}$. Tubes containing the samples were covered with foil (to avoid evaporation) and were boiled for 20-30 min. Tubes were shaken and cooled in ice. Two millilitres of $95 \% \mathrm{EtOH}$ was then added to precipitate glycogen from the digested solution. The samples were then shaken again and incubated in ice for $30 \mathrm{~min}$. Tubes were centrifuged at $22,000 \mathrm{~g}$ for $30 \mathrm{~min}$. Supernatant was removed and the pellets (glycogen) were re-dissolved in $1 \mathrm{~mL}$ of distilled water before being shaken. Standard glycogen solutions ( $0,25,50,75$ and $100 \mathrm{mg} / \mathrm{mL})$ were prepared before adding $5 \%$ phenol. Incubation was performed in an ice bath for 30 min. Standards and samples were read at $492 \mathrm{~nm}$ (Chun \& Yin, 1998).

\section{Protein determination}

Protein concentrations were assayed according to the method described by Lowry et al. (1951). In the assay, $20 \mu \mathrm{L}$ of the sample and $100 \mu \mathrm{L}$ of reagent were incubated for $30 \mathrm{~min}$ prior to reading the absorbance at $545 \mathrm{~nm}$ (recommended by ZiestChem. Co., Tehran, Iran).

\section{Assay of alanine (EC 2.6.1.2) and aspartate (EC 2.6.1.1) aminotransferases}

Alanine aminotransferase (ALT) and aspartate aminotransferase (AST) were measured using Thomas' (1998) procedure. The assays were performed with AST and ALT kits (Biochem Co., Tehran, Iran). 
Reagents 1 and 2 were mixed (4:1), samples were added and absorbance was read at $492 \mathrm{~nm}$.

\section{Assay of acid (EC 3.1.3.2) and alkaline (EC 3.1.3.1) phosphatase}

The enzyme assays were carried out as described by Bessey et al. (1946). The buffered substrate (phosphate buffer, $0.02 \mathrm{M}, \mathrm{pH}$ 7.2) was incubated with samples for $30 \mathrm{~min}$. Alkali was added to stop the reaction and to adjust the $\mathrm{pH}$ for determination of the formed product concentration. The spectral absorbance of $p$-nitrophenolate was maximal at $310 \mathrm{~nm}$. The molar absorbance of $p$-nitrophenolate at $400 \mathrm{~nm}$ is approximately double that of $p$-nitrophenyl phosphate at $310 \mathrm{~nm}$. On converting the $p$-nitrophenolate into $p$-nitrophenol by acidification, the absorption maximum shifted to approximately $320 \mathrm{~nm}$ with no detectable absorption at $405 \mathrm{~nm}$.

\section{Assay of lactate dehydrogenase (EC 1.1.1.27)}

King's (1965) method was used to evaluate the presence of lactate dehydrogenase (LDH). Test tubes were prepared containing $1 \mathrm{~mL}$ of the buffered substrate and $0.01 \mathrm{~mL}$ of the sample. To standardise volumes, $0.2 \mathrm{~mL} \mathrm{NAD}^{+}$solution was added to the test tubes of the sample group and $0.2 \mathrm{~mL}$ of water was added to the test tubes of the control group. Test tube samples were incubated for $15 \mathrm{~min}$ at $37^{\circ} \mathrm{C}$. The reactions were then arrested by adding $1 \mathrm{~mL}$ of colour reagent (2,4-dinitrophenyl hydrazine) to each tube, after which incubation was continued for an additional $15 \mathrm{~min}$. The contents were cooled at room temperature, and $10 \mathrm{~mL}$ of $0.4 \mathrm{~N} \mathrm{NaOH}$ was added to each tube to make the solutions strongly alkaline. At $60 \mathrm{~s}$ after the addition of alkali to each tube, the intensity of colour was measured at $454 \mathrm{~nm}$.

\section{Statistical analysis}

All data were tested for normality before analysis. Data were analysed by one-way analysis of variance (ANOVA) followed by comparison of the means with Tukey's post-hoc honestly significant difference test at $\alpha=0.05$ using statistical software SPSS 16.0 (StataCorp., College Station, TX, USA).

\section{Results}

\section{Effect of various host plants on digestive enzymes activity}

Activities of carbohydrases, triacylglyceride-lipase and general protease

Activity of carbohydrases in the midgut of $C$. chalcites larvae showed significant changes among various host plants $[\mathrm{F}=65.173 ; \mathrm{Pr}$ $(>F)=0.000$ (Figure 1A and B)]. The highest activities of $\alpha$-amylase, $\alpha$ and $\beta$-glucosidases were observed on dill $[\mathrm{F}=65.533$ and 14.670; $\mathrm{Pr}$ $(>\mathrm{F})=0.000$ and 0.005 (Figure 1B)]. The highest activity of general protease was observed on corn in comparison with other host plants $[\mathrm{F}=9.901 ; \operatorname{Pr}(>\mathrm{F})=0.002$ (Figure 2)]. Also, the enzymatic activity of TAGlipase in the larvae of $C$. chalcites significantly increased on corn as compared with dill and lemon balm $[\mathrm{F}=6.425 ; \operatorname{Pr}(>\mathrm{F})=0.032$ (Figure 2)].

\section{Specific proteolytic activities}

Activities of serine proteases (trypsin, chymotrypsin and elastease) showed statistical differences in the larvae of $C$. chalcites fed on the different host plants [F=31.314, 704.632 and 95.999; $\operatorname{Pr}(>\mathrm{F})=0.000$, 0.000 and 0.000 (Table 1)]. The serine proteases had the highest activities on dill in comparison with other hosts. Figure 3 indicates compar- ison of aminopeptidase and carboxypeptidase activities in the larvae of C. chalcites, demonstrating statistical differences among different host plants [ $F=24.472$ and 72.538; $\operatorname{Pr}(>F)=0.001$ and 0.000 (Figure 3 )]. The activity of these enzymes significantly increased on dill compared with the other hosts.

\section{Effects of various host plants on storage components of the fat body}

Although the highest amount of triacylglyceride was found in the fat bodies of larvae fed on corn, the larvae fed on dill showed the highest amounts of glycogen and total protein $[\mathrm{F}=16.766$ and 6.711 ; Pr $(>\mathrm{F})=0.003$ and 0.008 (Table 2)].

\section{Effects of various host plants on some enzymatic components involved in intermediary metabolism}

Significant differences were found among activities of ALT and AST, acid (ACP) and alkaline (ALP) phosphatase, as well as LDH in the haemolymph of larvae reared on lemon balm, corn and dill, respectively. The activity of ALT showed the highest activity on dill in comparison with other host plants $[F=10.905 ; \operatorname{Pr}(>F)=0.001$ (Table 3$)]$. The enzymatic activity of ACP significantly decreased on dill as compared with lemon balm and corn [F=13.58; $\operatorname{Pr}(>\mathrm{F})=0.001$ (Table 3)]. Also, activities of ALP and AST in the larvae of $C$. chalcites were the lowest on lemon balm $[\mathrm{F}=20.30$ and $3.95 ; \operatorname{Pr}(>\mathrm{F})=0.000$ and 0.042 (Table 3)]. The activity of LDH significantly increased on dill compared with the other host plants $[\mathrm{F}=8.666 ; \operatorname{Pr}(>\mathrm{F})=0.017$ (Table 3$)]$.

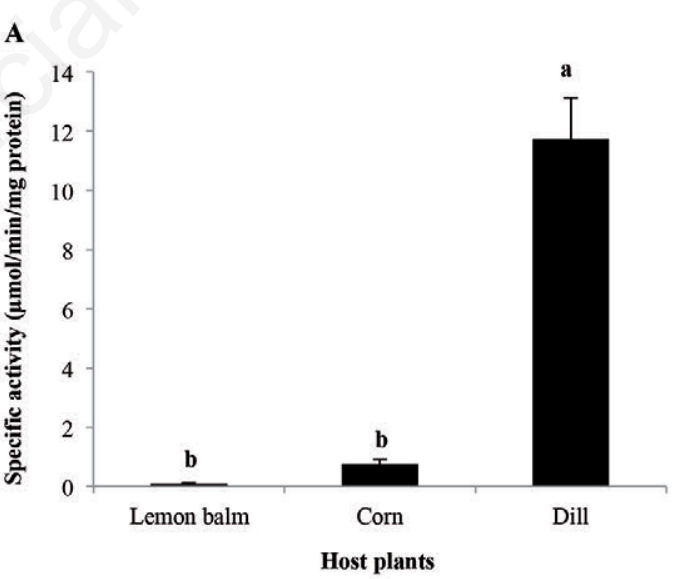

B

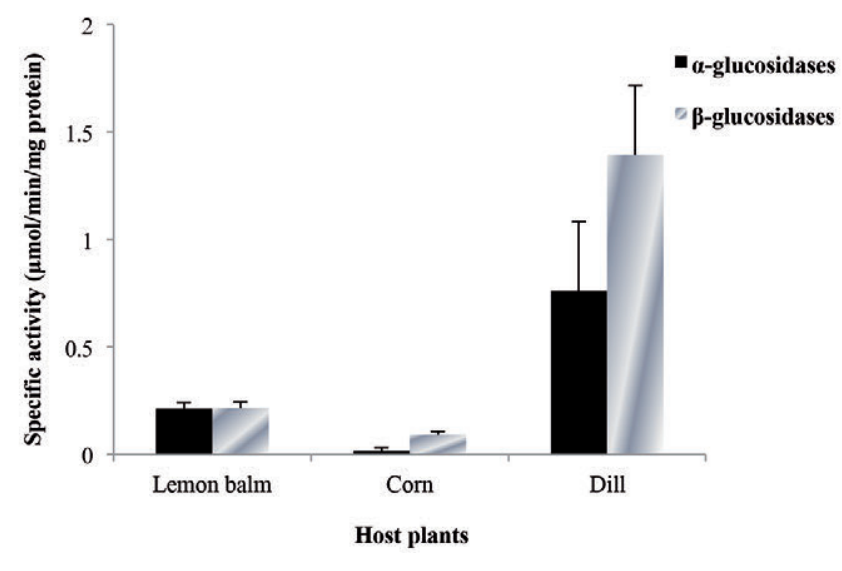

Figure 1. Comparison of $\alpha$-amylase (A), $\alpha$ - and $\beta$-glucosidases (B) activities in $C$. chalcites larvae reared on different host plants. 


\section{Discussion and conclusions}

The quality of host plants describes the their tissue components (e.g., the levels of protein, carbohydrate, trace elements and defensive compounds) that can positively or negatively affect feeding and digestion in herbivorous insects. Possible differences in secondary components or nutrient quality of host plants may influence survival, growth, fecundity and development time (Berynes \& Chapman, 1994). Alternatively, phytochemical changes in host plants can influence digestive enzyme activities. In the current study, $\alpha$-amylase and glucosidase activities of $C$. chalcites larvae were higher on dill than the other two hosts, indicating that dill is a suitable host plant for the golden twin spot, whose larvae can utilise carbohydrates as essential nutrients in the leaves (Agusti \& Cohen, 2000). In contrast, general proteolytic activities of $C$. chalcites larvae fed on corn were the highest

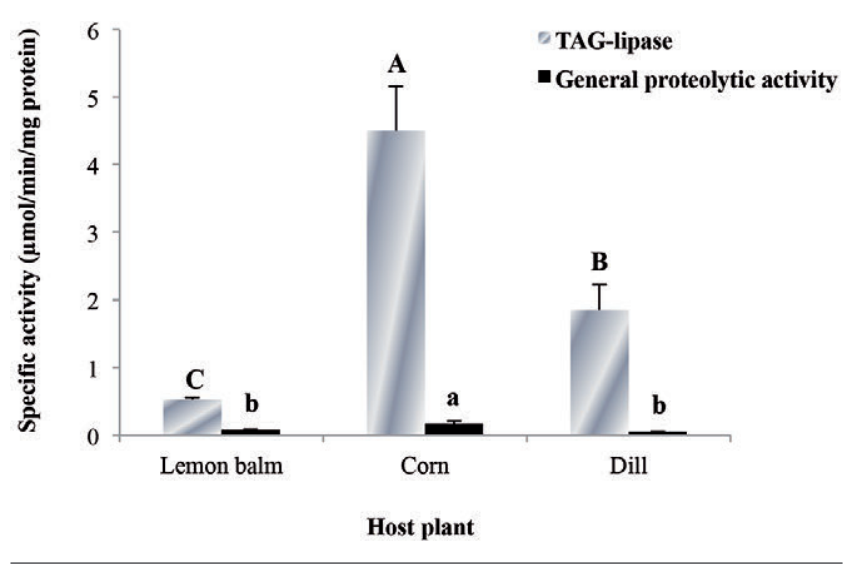

Figure 2. Comparison of lipase and general proteolytic activities in $C$. chalcites larvae reared on different host plants. TAG, triacylglyceride.

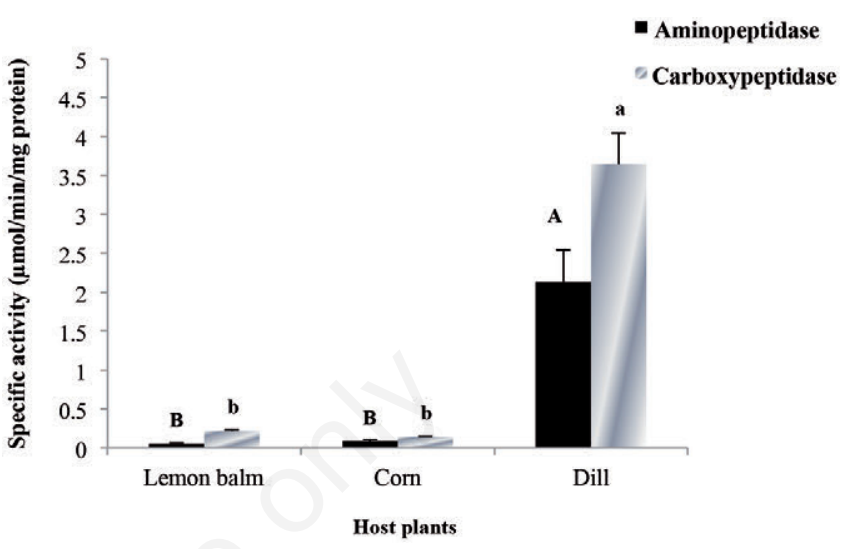

Figure 3. Comparison of amino- and carboxypeptidase activities in $C$. chalcites larvae reared on different host plants.

Table 1. Effect of the different host plants on digestive specific proteases $C$. chalcites larvae.

\begin{tabular}{|c|c|c|c|}
\hline \multirow[t]{2}{*}{ Host plants } & \multicolumn{3}{|c|}{ Statistic (mean \pm SE U/mg protein) } \\
\hline & Trypsin & Chymotrypsin & Elastease \\
\hline Lemon balm & $2.685 \pm 0.851^{\mathrm{b}}$ & $4.982 \pm 0.028^{b}$ & $0.917 \pm 0.101^{\mathrm{b}}$ \\
\hline Corn & $2.847 \pm 0.032^{\mathrm{b}}$ & $6.432 \pm 0.259^{b}$ & $0.113 \pm 0.043^{b}$ \\
\hline Dill & $34.154 \pm 5.669^{\mathrm{a}}$ & $94.547 \pm 3.336^{\mathrm{a}}$ & $56.679 \pm 5.732^{\mathrm{a}}$ \\
\hline
\end{tabular}

SE, standard error. a,bMeans followed by different letters in the same column are significantly different $(\mathrm{P}<0.05$, Tukey's post-hoc honestly significant difference $)$.

Table 2. Effect of the different host plants on amount of triacylglyceride, glycogen and total protein of C. chalcites larvae.

\begin{tabular}{|c|c|c|c|}
\hline Host plants & TAG (mg/mL) & Glycogen $(\mathrm{mg} / \mathrm{mL})$ & Total protein (mg) \\
\hline Lemon balm & $0.025 \pm 0.002^{b}$ & $0.025 \pm 0.001^{\mathrm{a}}$ & $0.171 \pm 0.008^{\mathrm{a}}$ \\
\hline Corn & $0.211 \pm 0.054^{\mathrm{a}}$ & $0.016 \pm 0.001^{b}$ & $0.029 \pm 0.005^{b}$ \\
\hline Dill & $0.047 \pm 0.002^{b}$ & $0.030 \pm 0.003^{\mathrm{a}}$ & $0.180 \pm 0.007^{\mathrm{a}}$ \\
\hline
\end{tabular}

SE, standard error; TAG, triacylglyceride. a, $\mathrm{b}$ Means followed by different letters in the same column are significantly different ( $\mathrm{P}<0.05$, Tukey's post-hoc honestly significant difference).

Table 3. Effect of the different host plants on specific activities of enzymatic components in intermediary metabolism of $C$. chalcites larvae.

\begin{tabular}{lccccc} 
& \multicolumn{5}{c}{ Statistic (mean \pm SE U/mg protein) } \\
Host plants & ALP & ACP & AST & ALT & LDH \\
Lemon balm & $0.799 \pm 0.038^{\mathrm{a}}$ & $0.249 \pm 0.008^{\mathrm{a}}$ & $0.012 \pm 0.003^{\mathrm{b}}$ & $0.011 \pm 0.003^{\mathrm{b}}$ & $0.096 \pm 0.033^{\mathrm{b}}$ \\
Corn & $0.773 \pm 0.081^{\mathrm{a}}$ & $0.254 \pm 0.075^{\mathrm{a}}$ & $0.051 \pm 0.004^{\mathrm{a}}$ & $0.039 \pm 0.011^{\mathrm{b}}$ & $0.090 \pm 0.017^{\mathrm{b}}$ \\
\hline Dill & $0.575 \pm 0.056^{\mathrm{a}}$ & $0.001 \pm 0.000^{\mathrm{b}}$ & $0.071 \pm 0.013^{\mathrm{a}}$ & $0.307 \pm 0.062^{\mathrm{a}}$ & $0.348 \pm 0.007^{\mathrm{a}}$ \\
\hline
\end{tabular}

SE, standard error; ALP, alkaline phosphatase; ACP, acid phosphatase; AST, aspartate aminotransferase; ALT, alanine aminotransferase; LDH, lactate dehydrogenase. a,bMeans followed by different letters in the same column are significantly different $(\mathrm{P}<0.05$, Tukey's post-hoc honestly significant difference). 
among the host plants assessed, although no significant difference was observed between lemon balm and dill. According to our findings, the highest specific proteolytic activities (trypsin, chymotrypsin, elastease, amino- and carboxypeptidases) were observed on dill, with no significant difference between lemon balm and corn. Higher activities of these enzymes indicate the presence of suitable proteins in the host plants for insect performance. Several studies have reported that various host plants had significantly different influences on proteolytic activities in the larvae of Helicoverpa armigera (Hübner) and Ectomyelois ceratoniae (Zeller) (Kotkar et al., 2009; Teimouri et al., 2013). TAG-lipases play important roles in the hydrolysis of intracellular TAG into diacylglyceride in addition to their role in the digestion of dietary lipids (Terra and Ferriera, 2005). Although Jafari (2014) showed that activities of the enzymes in the larvae of $C$. suppressalis fed on various rice varieties were not significantly different, Teimouri et al. (2013) reported significant differences in lipase activities of $E$. ceratoniae larvae reared on different diets.

Triacylglyceride, glycogen and total proteins are the three main storage macromolecules in insect fat bodies. Because there are variable amounts of these molecules in host plants, utilisation of different plants might lead to a gain in various levels of storage macromolecules in insects. In the current study, the highest amount of TAG was found in the larvae fed on corn, while the highest amounts of other two molecules were obtained in the larvae fed on dill. As lipids are one of the main components of corn seeds, leaves of the plant may produce more lipids than do other host plants. Therefore, larval feeding on corn leads to higher amounts of TAG in those larvae. Regarding insect energy demands, lipids are considered to be the most important class of nutrients because of their use as fuel in many physiological processes such as flight, reproduction, etc. Glycogen occurs later in these processes, but proteins are mainly used in tissue repair and for other enzymatic processes. Therefore, larvae fed on corn might fare better in reproduction or other activities when they reach the adult stage.

Intermediary metabolism is a complicated phenomenon in which energy is provided for biological activities via several processes, such as detoxification of xenobiotics, etc. In the current study, it was demonstrated that various host plants had significant differences on ALT and AST activities in the haemolymph of $C$. chalcites. The highest activity was found in the larvae fed on dill. These two enzymes are the transaminases that are present in haemolymph and fat bodies of insects (Nation, 2008). ALT catalyses the two parts of the alanine cycle in proline metabolism, while AST facilitates the conversion of aspartate and $\alpha$-ketoglutarate to oxaloacetate and glutamate (Nation, 2008). Higher activities of these enzymes on dill may indicate the presence of higher amounts of protein in dill, for possible use of amino acids in tissue development, excretion, and energy demands. These proteins must be stored in fat bodies, and excess amounts must be excreted because of their harmful effects. In the present study, the highest activities of ACP were found in the larvae fed on corn and lemon balm, but no statistical differences were found in the case of ALP. ACP and ALP hydrolyse phosphate groups of several molecules, including nucleotides, proteins, and alkaloids in alkaline and acidic conditions through dephosphorylation (Zibaee et al., 2011). Several phenomena, such as efficiency of digestion and transportation of nutrients in the midgut as well as haemolymph, significantly affect activities of these enzymes (Zibaee $e t$ al., 2011). Lactate dehydrogenase re-cycles pyruvate and lactate with concomitant inter-conversion of NADH and NAD+ (Kaplan \& Pesce, 1996). The highest amount of LDH was obtained in the larvae fed on dill, where the highest amount of glycogen was found. These findings demonstrate that larvae fed on dill gain higher levels of polysaccharides that are stored as glycogen. These larvae may depend on glycogen rather than TAG for their biological activities, and this dependence may cause higher activities of LDH.

Results of the current study describe the effects of three host plants on digestive enzymatic activities and the intermediary metabolism of C. chalcites larvae. An understanding of differences in food quality among host plants, presence of secondary components and possible inhibitors from a wider range of host plants is necessary for designing stable planting systems. Screening of resistance host plants is the best way to decrease economic loss from polyphagous pests. Moreover, extraction of molecules responsible for this resistance could be a promising way to provide new varieties via biotechnological procedures.

\section{References}

AGUSTI N., COHEN A.C., 2000 - Salivary and anterior mid-gut digestive enzymes from Lygushesperus and L. lineolaris. - J. Entomol. Sci. 35: $176-186$.

BERNFELD P., 1955 - Amylases, $\alpha$ and $\beta$. - Meth. Enzymol. 1: 149-158.

BERNYS E.A., CHAPMAN R.F., 1994 - Host-plant selection by phytophagous insects. - Chapman and Hall, New York.

BESSEY 0.A., LOWRY 0.H., BROCK M.J., 1946 - A method for the rapid determination of alkaline phosphatase with five cubic millimeters of serum. - J. Biol. Chem. 164: 321-329.

BITTENCOURT-RODRIGUES R., ZUCOLOTO F.S., 2005 - Effect of host age on the oviposition and performance of Ascia monuste Godart (Lepidoptera: Pieridae). - Neotrop. Entomol. 34: 169-175.

BROZA M., SNEH B., 1994 - Bacillus thuringiensisspp. kurstakias an effective control agent of lepidopteran pests in tomato fields in Israel. - J. Econ. Entomol. 87: 923-928.

CHEW F.S., RENWICK J.A.A. 1995 - Chemical ecology of host-plant choice in Pieris butterflies. In: CARDÉ R.T., BELL W.J. (Eds.), Chemical ecology of insects, $2^{\text {nd }}$ ed. Chapman \& Hall, New York, pp. 214-238.

CHUN Y., YIN Z.D., 1998 - Glycogen assay for diagnosis of female genital Chlamydia trachomatis infection. - J. Clin. Microbiol. 36: 1081-1082.

COHEN A.C.V., 1993 - Organization of digestion and preliminary characterization of salivary trypsin-like enzymes in a predaceous heteropteran, Zelusrenardii. - J. Insect. Physiol. 39: 823-829.

FOLIN 0., CIOCALTEU V., 1927 - On tyrosine and tryptophane determinations in proteins. - J. Biol. Chem. 73: 627-650.

FOSSATI P., PRENCIPE L., 1982 - Serum triglycerides determined colorimetrically with an enzyme that produces hydrogen peroxide. Clin. Chem. 28: 2077-2080.

G00DEY B., 1991 - Chrysodeixis chalcites - observations on the life cycle in captivity. Entomol. Rec. 103: 111-118.

HSIAO T.H., FRAENKEL G., 1968 - Selection and specificity of the colorado potato beetle for solanaceous and nonsolanaceous plants. Ann. Entomol. Soc. Am. 61: 493-503.

JAFARI H., 2014 - Effect of five rice varietes on digestive enzymes activity of larvae rice stem borer Chilo suppressalis Walker (Lep; Crambidae). Degree thesis, University of Mohaghegh-Ardabili, Ardabile, Iran.

KAPLAN L.A., PESCE A.J., 1996 - Clinical chemistry. Theory analysis and correlation. Mosby-Year Book, St. Louis, MO.

KING J., 1965 - The dehydrogenases or oxidoreductases. Lactate dehydrogenase. In: D. Van Nostrand (Ed.), Practical clinical enzymology. - Van Nostrand Company Ltd., London, pp. 83-93.

KOTKAR H.M., SARATE P.J., TAMHANE V.A., GUPTA V.S., GIRI A.P., 2009 - Responses of midgut amylases of Helicoverpa armigera feeding on various host plants. - J. Insect Physiol. 55: 663-670.

LOWRY 0.H., ROSEBROUGH N.J., FARR A.L., RANDALL R.J., 1951 Protein measurement with the Folin phenol reagent. - J. Biol. Chem. 193: 265-275.

NATION J.L., 2008 - Insect physiology and biochemistry, $2^{\text {nd }}$ ed. CRC press, London.

RASHID F.F., HAMMAD S.M., HASSAN S.M., 1971 - The biology of 
Autographa chalcites L. in Alexandria region (Lepidoptera: Noctuidae). - Bull. Soc. Entomol. Egypt. 55: 419-426.

RYAN C.A., 1990 - Protease inhibitors in plants: genes for improving defenses against insect and pathogens.- Annu. Rev. Phytopathol. 28: 425-449.

SILVA C.P., TERRA W.R.M, 1995 - An a-glucosidase from perimicrovillar membranes of Dysdercus peruvianus (Hemiptera: Pyrrhocoridae) midgut cells: purification and properties. -Insect. Biochem. Mol. Biol. 25: 487-494.

SIMPSON S.J., RAUBENHEIMER D., 1999 - Assuaging nutritional complexity: a geometricalapproach. - Proc Nutr Soc 58: 779-789.

TAYLOR D.E., KUNJEKU E., 1983 - Development of an economic threshold for semi-loopers (Lepidoptera: Noctuidae) on soya-beans in Zimbabwe. - Zimbabwe J. Agric. Res. 2: 89-100.

TEIMOURI N., SENDI J.J., ZIBAEE A., KHOSRAVI R., 2013 - Feeding indices and enzymatic activities of carob moth Ectomyelois ceratoniae (Zeller) (Lepidoptera: pyrallidae) on two commercial pistachio cultivars and an artificial diet. - J. Saudi Soc. Agri. Sci. [In press].

TERRA W.R., FERRIERA C., 2005 - Biochemistry of digestion. In: LAWRENCE I.G., KOSTAS I., SARJEET S.G. (Eds.), Comprehensive molecular insect science. Vol. 3. - Elsevier, Oxford, pp. 171-224.

THOMAS L., 1998 - Clinical laboratory diagnostic, $1^{\text {st }}$ ed. - TH Books Verlasgesellschaft, Frankfurt, pp. 89-94.

TSUJITA T., NINOMIYA H., OKUDA H., 1989 - p-nitrophenyl butyrate hydrolyzing activity of hormone-sensitive lipase from bovine adipose tissue. - J. Lipid. Res. 30: 997-1004.

ZIBAEE A., ZIBAEE I., SENDI J.J., 2011. - A juvenile hormone analogue, Pyriproxifen, affects some biochemical components in the hemolymph and fat bodies of Eurygaster integriceps Puton (Hemiptera: Scutelleridae). - Pestic. Biochem. Physiol. 100: 289-298. 